\title{
Ecotoxicity screening of novel phosphorus adsorbents used for lake restoration
}

\author{
Álvarez-Manzaneda, I.; Baun, Anders; Cruz-Pizarro, L.; de Vicente, I.
}

Published in:

Chemosphere

Link to article, DOI:

10.1016/j.chemosphere.2019.01.103

Publication date:

2019

Document Version

Peer reviewed version

Link back to DTU Orbit

Citation (APA):

Álvarez-Manzaneda, I., Baun, A., Cruz-Pizarro, L., \& de Vicente, I. (2019). Ecotoxicity screening of novel phosphorus adsorbents used for lake restoration. Chemosphere, 222, 469-478.

https://doi.org/10.1016/j.chemosphere.2019.01.103

\section{General rights}

Copyright and moral rights for the publications made accessible in the public portal are retained by the authors and/or other copyright owners and it is a condition of accessing publications that users recognise and abide by the legal requirements associated with these rights.

- Users may download and print one copy of any publication from the public portal for the purpose of private study or research.

- You may not further distribute the material or use it for any profit-making activity or commercial gain

- You may freely distribute the URL identifying the publication in the public portal

If you believe that this document breaches copyright please contact us providing details, and we will remove access to the work immediately and investigate your claim. 


\title{
Ecotoxicity screening of novel phosphorus adsorbents used for lake restoration
}

\author{
I. Álvarez-Manzaneda ${ }^{1,2}$, A. Baun ${ }^{3}$, L. Cruz-Pizarro ${ }^{1,2}$ and I. de Vicente (2* $^{1,2}$ \\ ${ }^{1}$ Departamento de Ecología, Facultad de Ciencias, Universidad de Granada, 18071 \\ Spain \\ ${ }^{2}$ Instituto del Agua, Universidad de Granada, 18071 Spain \\ ${ }^{3}$ Department of Environmental Engineering, Technical University of Denmark, 2800 \\ Kgs. Lyngby, Denmark
}

*Corresponding author:

Departamento de Ecología, Facultad de Ciencias, Universidad de Granada, 18071, Granada (Spain)

Phone: (+34) 958 249768; Fax: (+34) 958 243093; email:ivicente@ugr.es

\begin{abstract}
Short-term standardized laboratory tests were carried out for evaluating acute and chronic toxicological effects of novel phosphorus (P) adsorbents on Raphidocelis subcapitata (algal growth rate inhibition) and on Daphnia magna (immobilization, with direct and indirect exposure to adsorbents, and uptake-depuration tests). Four $\mathrm{P}$ adsorbents were tested: two magnetic (HQ and $\left.\mathrm{Fe}_{3} \mathrm{O}_{4}\right)$ and two non magnetic $(\mathrm{CFH}-12 \AA$ and Phoslock $囚)$. For the case of the algal growth inhibition test, the $\mathrm{EC}_{50}$ was 1.5 and $0.42 \mathrm{~g} \mathrm{~L}^{-1}$ for $\mathrm{HQ}$ and $\mathrm{CFH}-12 \AA$, respectively, and no inhibition patterns were observed neither for $\mathrm{Fe}_{3} \mathrm{O}_{4}$ nor for Phoslock®. When organisms were exposed to a direct contact, in the D. magna immobilization test, no statistically significant differences were found in the $\mathrm{EC}_{50}$ values among the four studied adsorbents. The huge difference between direct and indirect contact experiments suggests that toxicity is mainly physically mediated. The uptake-depuration test evidenced a much faster uptake and depuration rates for Phoslock ${ }^{\circledR}$, which was precisely the adsorbent with the highest particle size. In a realistic worst-case scenario using data from Honda lake (Almería, Spain), where lake restoration is carried out by a adding a single large dose to bind surplus $\mathrm{P}$ in the lake, the predicted environmental concentrations for all adsorbents were lower than $\mathrm{EC}_{50}$ for all adsorbents and they were found to exceed a provisional limit value for ecotoxicity after a short-term exposure. All in all, since neither accumulation nor longer term effects of $\mathrm{P}$ adsorbents in the pelagic phase is expected, this risk may however, on a case-to-case basis, be acceptable.
\end{abstract}

Keywords: phosphorus, Raphidocelis subcapitata, Daphnia magna, toxicity, eutrophication, lake restoration

\section{Introduction}

Since the seventies, eutrophication has been recognized as a key problem impairing the quality of worldwide water resources (Cooke et al., 2005; OECD, 1982; Sas, 1989). As phosphorus $(\mathrm{P})$ is the main limiting nutrient for primary production in aquatic freshwater ecosystems, the first attempt for restoring eutrophicated systems is based on reducing $\mathrm{P}$ concentration in the aquatic ecosystems. This reduction can be achieved by decreasing external and internal (from the sediment) $\mathrm{P}$ loads and by increasing $\mathrm{P}$ export from the systems (Hupfer and Hilt, 2008).

Actually, one of the most promising methods consists on adding P-sorbing materials (e.g. modified clays, industrial by-products, flocculants and physical barriers) for stripping $\mathrm{P}$ from the water column and making it non-bioavailable for primary producers (Spears et al., 2016). Iron (Fe) and Aluminum ( $\mathrm{Al}$ ) oxides have been traditionally used for lake restoration (Cooke et al., 2005). Although Fe oxides are 
characterized by a high $\mathrm{P}$ adsorption capacity, the permanent $\mathrm{P}$ fixation requires in most cases continuous complete mixing or aeration (Jeppesen et al., 2009) due to the fact that $\mathrm{Fe}$ oxides are highly redox sensitive. Furthermore, $\mathrm{Al}$ salts as alum $\left(\mathrm{Al}_{2}\left(\mathrm{SO}_{4}\right)_{3}\right)$ or polyaluminum chloride form solid $\mathrm{Al}(\mathrm{OH})_{3}$ with high affinity for $\mathrm{P}$ in lake water. Despite Al salts have been used in lakes around the world for nearly half a century (Kennedy et al., 1987; Landner, 1970), they present the next disadvantages: (i) the drop in lake water $\mathrm{pH}$ during the formation of $\mathrm{Al}(\mathrm{OH})_{3}$ floc; (ii) toxicity for the lake biota when $\mathrm{pH}$ is out of the range 6-8 (Lin et al., 2017; Nogaro et al., 2016; Pacioglu et al., 2016) and (iii) the strong reduction of $P$ adsorption capacity with time; as it has been found that $\mathrm{Al}(\mathrm{OH})_{3}$ lost $75 \%$ of the maximum $\mathrm{P}$ adsorption capacity in 90 days (de Vicente et al., 2008).

To counteract the mentioned limitations of both $\mathrm{Fe}$ and $\mathrm{Al}$ salts, novel $\mathrm{P}$ adsorbents have been recently proposed for restoring eutrophicated aquatic ecosystems. Lanthanum (La) modified bentonite (Phoslock ${ }^{\circledR}$ ) is being increasingly used in lakes for P control (Douglas et al., 2000; Robb et al., 2003; Spears et al., 2016). It was firstly developed by the Common Wealth Scientific and Industrial Research Organization (CSIRO, Australia; Finsterle, 2014) for adsorbing P from the water column and for increasing P sorption capacity of the sediment (Meis et al., 2012; Robb et al., 2003). Among the most important advantages of this compound we remark that it can be used in a wide $\mathrm{pH}$ (5-9) range and even under anoxic conditions (Meis et al., 2012; Robb et al., 2003). However, Phoslock ${ }^{\circledR}$ application also shows some drawbacks such as chemical interferences with humic substances or oxyanions (Lürling and Tolman, 2010; Lürling et al., 2014) and its high-economic cost (Spears et al., 2013). More recently, a dried amorphous Fe oxide, $\mathrm{CFH}-12 \AA$ (Kemira), has been proposed as a novel agent for lake restoration as (i) it does not change water $\mathrm{pH}$; (ii) it causes a notable $\mathrm{P}$ efflux reduction when it is added in a 7.6-8.1 Fe: $\mathrm{P}$ molar ratio and (iii) it is not dependent on redox conditions (Fuchs et al., 2018).

All the above mentioned (Phoslock ${ }^{\circledR}$ and $\mathrm{CFH}-12 \AA$ ) innovative adsorbents lack of the possibility of being recovered from the lake water. In this scenario, magnetic particles (MPs) have been recently proposed for lake restoration as MPs adsorb P and later P loaded MPs can be efficiently removed from solution by applying a magnetic separation gradient (de Vicente et al., 2010, 2011; Funes et al., 2016, 2017a; Merino-Martos et al., 2011, 2015). Therefore, the use of MPs may contribute to mitigate the two coupled and worldwide increasing problems affecting biogeochemical P cycle: (i) the eutrophication, nutrient enrichment, of aquatic ecosystems (de Jonge et al., 2002; Glibert, 2017; OECD, 1984; Withers et al., 2014) and (ii) the global reduction of $\mathrm{P}$ reserves (Cordell et al., 2011; Gilbert, 2009). In more detail, the underlying mechanism is that by one hand, MPs trap dissolved P with a minimal alteration in water quality (e.g. Funes et al., 2016, 2018) and on the other hand, P adsorbed on MPs can be desorbed, in basic solutions, and therefore recovered P can be eventually used as a fertilizer (Álvarez-Manzaneda et al., unpublished). Additional advantages of using MPs include: (i) high (18.83 $\mathrm{mg} \mathrm{P} \mathrm{g}^{-1}$ ) and fast (less than $1 \mathrm{~h}$ ) maximum $\mathrm{P}$ adsorption capacity; (ii) their magnetic properties allows for recovery of MPs from solution by applying a magnetic separation gradient; (iii) the non-dependence on redox conditions of their P adsorption properties; (iv) their lower economic cost compared to other $\mathrm{P}$ adsorbents (e.g. $\mathrm{AlCl}_{3} \cdot 6 \mathrm{H}_{2} \mathrm{O}$ or Phoslock ${ }^{\circledR}$ ) and (v) they can be easily supplied by companies (i.e. BASF) or by synthesis under laboratory conditions and hence, size and specific properties can be thoroughly selected (de Vicente et al., 2010; Funes et al. 2016, 2017b).

Despite of the increasing use of novel adsorbents for inactivating $\mathrm{P}$ in lake sediment, it is especially striking that few studies are focused on assessing their toxic effects on lake biota (Álvarez-Manzaneda and de Vicente, 2017; Álvarez-Manzaneda et al., 2017; Lürling and Tolman, 2010; van Oosterhout and Lürling, 2013; Yamada-Ferraz et al., 2015). In general, those studies are focussed on assessing lethal and sublethal effects of Phoslock ${ }^{\circledR}$ and MPs on planktonic and benthic organisms but no research on 
discrimination between physical and chemical effects nor on uptake and depuration availability were carried out. In this context, our working hypotheses are firstly, that $\mathrm{P}$ adsorbents used for lake restoration cause both chemical and physical effects on algae and on cladocerans and secondly, that cladocerans show fast uptake and depuration mechanisms when they are exposed to low concentration of $\mathrm{P}$ adsorbents. Accordingly, in this study we combine toxicity tests (inhibition growth and immobilization) and uptake-depuration tests. In particular, the general aim of this paper was to assess, by short-term laboratory tests and following ISO (International Standardization Organization) and OECD (Organization for Economic Cooperation and Development) protocols, the acute effects of two magnetic (carbonyl iron, $\mathrm{HQ}$ and magnetite, $\mathrm{Fe}_{3} \mathrm{O}_{4}$ ) and two non-magnetic P adsorbents (Phoslock ${ }^{\circledR}$ and $\left.\mathrm{CFH}-12 \AA\right)$ on both the green algae Raphidocelis subcapitata (growth rate inhibition test; ISO, 2012) and on D. magna (immobilization; OECD, 2004). To discriminate between chemical and physical effects of adsorbents on D. magna, the immobilization test was run both in direct and in indirect contact (by using a double beaker, Skjolding et al., 2016) with the different P adsorbents. Finally, an uptake-depuration test was carried out for assessing the response of $D$. magna after being in direct contact with adsorbents for $24 \mathrm{~h}$. In particular, temporal changes in $\mathrm{Fe}$ and La body burdens contents were monitored during $24 \mathrm{~h}$ uptake and $24 \mathrm{~h}$-depuration tests.

\section{Material and methods}

\subsection{Test organisms}

Laboratory experiments were carried out with two different species belonging to different trophic levels, the green algae $R$. subcapitata (Korshikov) and D. magna. The need for using phytoplankton toxicological tests is based on its sensitivity to contaminants (Hoffman et al., 2003) and its key role in the aquatic ecosystems (Lewis, 1995). $R$. subcapitata is an unicellular green algae (Chlorophyta) with crescent-shaped $\left(40-60 \mu \mathrm{m}^{3}\right)$, which can be found in eutrophic or oligotrophic epicontinental aquatic systems (Granados et al., 2004). The stock culture of $R$. subcapitata, provided by Department of Environmental Engineering of the Technical University of Denmark, was cultivated in the ISO 8692 medium (ISO, 2012).

Daphnia magna was selected among cladocerans as it is widely considered as an organism test in toxicity assays (García et al., 2011; Khangarot and Ray, 1987) and it is easily cultured in laboratory conditions (Núñez and Hurtado, 2005). D. magna has been cultured at the Department of Environmental Engineering of the Technical University of Denmark since 1978 from the original culture from Birkedammen, Denmark. The culture was maintained with 15 adult organisms kept in $800 \mathrm{~mL}$ of Elendt M7 medium $(\mathrm{OECD}, 2004)$ at $20 \pm 1^{\circ} \mathrm{C}$ and a $16: 8 \mathrm{~h}$ light-dark cycle. The daphnids were fed daily with $R$. subcapitata. Algal cell concentration was estimated using a Coulter Counter (Multisizer Z2, Beckman Coulter) attached to a computer with Coulter AccuComp version 3.01 software (Beckman Coulter Corporation 2000). The medium of the daphnids culture was renewed twice a week.

\subsection{General characterization of magnetic and non magnetic phosphorus adsorbents}

The most important features of the four selected P adsorbents are shown in Table 1. All were commercially supplied. They greatly differ in their chemical composition, size and maximum $\mathrm{P}$ adsorption capacity. Briefly, $\mathrm{HQ}$ and $\mathrm{Fe}_{3} \mathrm{O}_{4}$ have spherical shape, relative polydispersion and a ferromagnetic behavior. $\mathrm{CFH}-12 \AA$, manufactured by Kemira (Oyj, Finland), is a dried amorphous solid consisting of poorly ordered $\mathrm{Fe}$ oxides (Fuchs et al., 2018; Lyngsie et al., 2014). Finally, Phoslock® is a La-based (5\% La, 95\% clay) engineered product in which the presence of $\mathrm{Fe}$ and $\mathrm{Al}$ apart from $\mathrm{La}$, increases the number of P binding sites (Reitzel et al., 2013).

\subsection{Algal growth inhibition test}


The algal growth inhibition test was performed following the ISO Standard "Water quality - Fresh water algal growth inhibition test with unicellular green algae" (ISO, 2012). Chemical composition of algal growth medium is shown in Table 2. The concentrations of each adsorbent were $0.05,0.1,0.5,1$ and $1.5 \mathrm{~g} \mathrm{~L}^{-1}$ for $\mathrm{HQ}$ and $\mathrm{Fe}_{3} \mathrm{O}_{4}$; $0.02,0.04,0.1,0.24$ and $0.6 \mathrm{~g} \mathrm{~L}^{-1}$ for CFH-12® and $0.1,0.5,1,1.5$ and $2 \mathrm{~g} \mathrm{~L}^{-1}$ for Phoslock $囚$. These concentrations were selected in view of the results obtained in preliminary tests as ISO (2012) recommended. Each test comprised three replicates of each concentration and six untreated controls. The $\mathrm{pH}$ values and the $\mathrm{EC}_{50}$ obtained for the reference toxicity test were within the validity criteria specified by the guideline (ISO, 2012).

For the case of the two magnetic adsorbents ( $\mathrm{HQ}$ and $\mathrm{Fe}_{3} \mathrm{O}_{4}$ ), after $24 \mathrm{~h}$ of contact time, adsorbents were removed by applying a magnetic gradient exerted by a cylindrical teflon coated magnet $(50 \times 8 \mathrm{~mm})$. Once magnetic adsorbents were removed, algal cells $\left(50.000\right.$ cells $\left.\mathrm{mL}^{-1}\right)$ were inoculated. Test vessels $(20 \mathrm{~mL})$ were located for $48 \mathrm{~h}$ in an isolated room, on a shaker $(200 \mathrm{rpm})$ at $20 \pm 2^{\circ} \mathrm{C}$ and continuously illuminated at $100 \pm$ $15 \mu \mathrm{E} \mathrm{m}^{-2} \mathrm{~s}^{-1}$. In order to check possible changes in $\mathrm{pH}$ linked to adsorbents addition, $\mathrm{pH}$ was measured before and after MPs removal.

It is important to consider that a higher algal cell density than that recommended by ISO (2012) was used for a better discrimination between the background noise owing to particles and/or colored solutions and algal pigment fluorescence (Hartmann et al., 2013). The initial algal biomass of the stock culture was quantified before the inoculation, by using a Coulter Counter (Multisizer Z2, Beckman Coulter). Particle number was recorded as particle number per mL using the software Coulter AccuComp version 3.01 (Beckman Coulter Corporation 2000). Algal growth rates were estimated as a function of the fluorescence of algal pigments in acetone extracts (Mayer et al., 1997) by using a fluorescence spectrophotometer (Hitachi F-2000) at 430 and $670 \mathrm{~nm}$ excitation and emission wavelengths, respectively. In particular, samples $(0.4 \mathrm{~mL})$ were collected at 0,24 and $48 \mathrm{~h}$ in each vial. EC values (95\% confidence limits) and concentration-response curves were estimated by using a nonlinear-regression program (Christensen et al., 2009).

\subsection{Toxicity and uptake/depuration tests with Daphnia magna}

Tests were carried out following a standardized protocol (OECD, 2004) using HQ, $\mathrm{Fe}_{3} \mathrm{O}_{4}, \mathrm{CFH}-12 \AA$ and Phoslock ${ }^{\circledR}$ as test substances. Medium $\mathrm{pH}$ was adjusted to 8.0 according to the protocol. The test suspensions of each adsorbent were prepared by adding the required volume of a $10 \mathrm{~g} \mathrm{~L}^{-1}$ strongly shaked stock solution to $100 \mathrm{~mL}$ volumetric flasks containing Elendt M7 medium.

\subsubsection{Immobilization test by direct contact with adsorbents}

This test was carried out with $D$. magna neonates ( $<24 \mathrm{~h}$ old $)$ after testing the toxicity of the reference compound (potassium dichromate) as it is specified in the guideline (OECD, 2004). Preliminary tests were run for determining the appropriate concentrations of the four $\mathrm{P}$ adsorbents. Lastly, suspensions containing the following adsorbents concentrations were prepared: $0.0385 ; 0.096 ; 0.24 ; 0.6 ; 1.5 ; 2.25 ; 3$ and 3.75 $\mathrm{g} \mathrm{L}^{-1}$. Neonates were distributed in groups of five individuals and they were placed into $100 \mathrm{~mL}$ glass beakers containing $25 \mathrm{~mL}$ of the different concentrations. All glass beakers, comprising four replicates of all control and treatments, were randomly located at $20 \pm 1^{\circ} \mathrm{C}$ in the dark. Organisms were not fed during the experiment and the number of immobile animals, those who are not able to swim within $15 \mathrm{~s}$ after gentle agitation of the test vessel, was counted after 24 and $48 \mathrm{~h}$.

\subsubsection{Immobilization test by indirect contact with adsorbents}

For assessing indirect effects by the studied adsorbents, the same standard $48 \mathrm{~h}$ acute immobilization test (OECD,2004) as described in section 2.4.1, was carried out but using a double-beaker test setup. It consisted in using a net $(0.33 \times 0.33 \mathrm{~mm})$ which 
separate the neonates ( $<24 \mathrm{~h}$ old) from direct contact with any aggregated particles. The same adsorbent concentrations, number of exposed organisms and replicates were used as it is described in section 2.4.1. Finally, after 24 and $48 \mathrm{~h}$ at $20 \pm 1^{\circ} \mathrm{C}$ in the dark, the number of immobile animals was recorded. The organisms were stored in $75 \%$ nitric acid $\left(\mathrm{HNO}_{3}\right)$ and $\mathrm{Fe}$ and $\mathrm{La}$ content were determined by using spectrophotometry technique (ICP-OES).

\subsubsection{Uptake and depuration experiments}

An uptake-depuration test was carried out for each $\mathrm{P}$ adsorbent following the methodology described by Skjolding et al. (2014). Briefly, a $24 \mathrm{~h}$ uptake phase followed by a $24 \mathrm{~h}$ depuration period was performed by using a selected concentration of each adsorbent. These concentrations were lower than $\mathrm{EC}_{10}$ obtained in the immobilization test with $D$. magna in direct contact with the particles. Adsorbent concentrations were: $0.2 ; 0.5 ; 1.4$ and $0.05 \mathrm{~g} \mathrm{~L}^{-1}$ for $\mathrm{HQ}, \mathrm{Fe}_{3} \mathrm{O}_{4}, \mathrm{CFH}-12 \AA$ and Phoslock ${ }^{\circledR}$, respectively. The method consisted of placing five neonates $(<24 \mathrm{~h})$ in $25 \mathrm{~mL}$ of the selected adsorbent concentrations. All beakers were incubated at $20^{\circ} \mathrm{C}$ in the dark and organisms were sampled after 1, 2, 3, 4, 6 and $24 \mathrm{~h}$ of contact time. At each sampling time, mobile neonates of three beakers were collected for measuring their $\mathrm{Fe}$ and $\mathrm{La}$ content, similarly as it is described in the previous experiment (section 2.4.2). Three beakers were additionally included as control treatments. For the depuration test, after $24 \mathrm{~h}$ of exposition, the mobile organisms were transferred to pure medium. Again, the beakers were located in the dark at $20^{\circ} \mathrm{C}$ and mobile organisms from three beakers were collected at 1, 2, 3, 4, 6 and $24 \mathrm{~h}$. Finally, Fe and La content in the daphnids was measured similarly to it has been described above.

The natural logarithm of the data was fitted to a linear regression to determine the uptake and depuration rate constants $\left(\mathrm{K}_{\mathrm{u}}\right.$ and $\left.\mathrm{K}_{\mathrm{d}}\right)$. Moreover, the elimination half-life $\left(\mathrm{t}_{1 / 2}\right)$, which can be defined as the time that the particles stay inside the organisms once the exposure has stopped, was also calculated as Djomo et al. (1996) indicated:

$t_{\frac{1}{a}}=\frac{\operatorname{Ln} 2}{K_{d}}$

\subsection{Statistical analysis}

Concentration-response curves and mean effective concentration $\left(\mathrm{EC}_{50}\right)$ of the growth inhibition test with $R$. subcapitata were described by a log-logistic equation, fitted by least squares, and estimated by using a nonlinear-regression program (Christensen et al., 2009). $\mathrm{EC}_{50}$ and corresponding $95 \%$ confidence limits for the D. magna immobilization (under direct and indirect contact) tests were estimated by using Probit analysis with the program SPSS. In addition, statistical differences when comparing $\mathrm{EC}_{50}$ values were reported when non-overlapping confidence limits occurred (Abot et al., 1995; Jeske et al., 2009; Liu et al., 2003).

Finally, in order to deliver data for a preliminary risk assessment of the four studied adsorbents, predicted environmental concentrations (PEC) and predicted no-effect concentrations (PNEC) were calculated. PNEC was estimated as the lowest $\mathrm{EC}_{50}$ found in algal or daphnia tests divided by an assessment factor of 1000 in accordance with the Technical Guidance Document for setting environmental quality standards in the Water Framework Directive (TGD-EQS, 2011). The PNEC forms the basis for determining the relevant environmental quality standard. Since adsorbents are added once in lake restorations, continuous exposure to adsorbents is not expected to occur in receiving water bodies. The environmental quality standard of relevance is hence the so-called "MAC-QSfw,eco", i.e. the maximum allowable concentration for the freshwater ecosystem (TGD-EQS, 2011). For this an assessment factor of 100 was chosen, in accordance with the TGD-EQS (2011), and thus the MAC-QSfw,eco for all compounds was 10 times higher than the PNEC (see Table 4). Additionally, a realistic worst-case PEC was calculated for a real case application in a hypertrophic ecosystem: Honda lake 
(Almería, Spain). Estimations were based on: (i) the mass of mobile $\mathrm{P}$ in the upper sediment layer (0-10 cm; Funes et al., 2017a); (ii) lake morphometry and (iii) maximum $\mathrm{P}$ adsorption capacity of each adsorbent.

\section{Results and discussion}

\subsection{Algal growth rate inhibition tests}

Results from $R$. subcapitata growth rate inhibition tests differed markedly among the four $\mathrm{P}$ adsorbents. While no pattern of algal growth rate inhibition was observed for $\mathrm{Fe}_{3} \mathrm{O}_{4}$ and Phoslock ${ }^{\circledR}, \mathrm{EC}_{50}$ for HQ and $\mathrm{CFH}-12{ }^{\circledR}$ was $1.50[1.46 ; 1.54]_{95 \%}$ and $0.42 \mathrm{~g} \mathrm{~L}^{-}$ ${ }^{1}[0.35 ; 0.51]_{95 \%}$, respectively. It should be noted that the $\mathrm{EC}_{50}$ for HQ was much higher than the $0.085 \mathrm{~g} \mathrm{~L}^{-1}$ found in a similar experiment with Chlorella sp. (ÁlvarezManzaneda and de Vicente, 2017), in which the inhibition of the cell growth was recorded. These differences can be due to interspecies differences in sensitivity (Menard et al., 2011) and they may also be related to methodological aspects such as contact time (48 $\mathrm{h}$ in this experiment and $72 \mathrm{~h}$ in Álvarez-Manzaneda and de Vicente, 2017) and different medium composition as described by e.g. Chen and Lin (1997) and Millington et al. (1988).

As it was expected, inhibition of algal growth rates increased with $\mathrm{CFH}-12 \AA$ particles concentration (Figure 1). It should be mentioned that CFH-12® suspension was redcolored and a shading effect cannot be excluded as Sørensen et al. (2016) found for platinum nanoparticles.

For $\mathrm{Fe}_{3} \mathrm{O}_{4}$, the lack of any pattern could be explained by the stimulation of the algal growth due to the presence of dissolved Fe in the media $\left(13 \mu \mathrm{g} \mathrm{L}^{-1}\right)$. It is very wellknown that, of all the trace metals, $\mathrm{Fe}$ is especially prominent in biochemical catalysis (Morel and Price, 2003; Shcolnick and Keren, 2006) and phytoplankton, with their Fe-rich photosynthetic apparatus, have significantly higher Fe demands as opposed to their heterotrophic counterparts (Raven et al., 1999). In the algal medium Fe is added to a final concentration of $64 \mu \mathrm{g} \mathrm{L}{ }^{-1}$ which is the minimum to support an exponential growth of $R$. subcapitata for $72 \mathrm{~h}$ under the specified test conditions (ISO, 2012). Thus, the additional dissolved $\mathrm{Fe}$ present in the $\mathrm{Fe}_{3} \mathrm{O}_{4}$ tests $\left(13 \mu \mathrm{g} \mathrm{L}^{-1}\right)$ represents a significant increase in available Fe to support enhanced algal growth. In relation to Phoslock®, no pattern of algal growth rate inhibition was observed in the tested concentration range $(<$ $\left.2 \mathrm{~g} \mathrm{~L}^{-1}\right)$. Our results are in disagreement with the results found by van Oosterhout and Lürling (2013) in an experiment with Phoslock ${ }^{\circledR}$ in contact with Scenedesmus obliquus and Microcystis aeruginosa. These authors noted that growth rates of the green alga and of the cyanobacterium were negatively affected when Phoslock® concentration was higher than $0.5 \mathrm{~g} \mathrm{~L}^{-1}$, which is actually much lower than that used in the present study. Again, these differences may be explained by differences in the medium used for each test as well as in the different test organisms. In fact, since the test medium used by van Oosterhout and Lürling (2013) has higher contents of macro- and micronutrients, these differences may be related to differences in species sensitivity to Phoslock®.

Finally, it is important to consider that the growth of microalgae is strongly affected by nutrient availability and accordingly, if $\mathrm{P}$ adsorbents cause a notable reduction in $\mathrm{P}$ concentration a potential limitation of primary production may occur. Although, in this study we have not been focused on monitoring changes in $\mathrm{P}$ concentrations when adding P adsorbents, a previous study (Álvarez-Manzaneda \& de Vicente, 2017) noted that when adding MPs concentrations similar to those used in this study, $\mathrm{P}$ concentrations were still much higher than $\mathrm{P}$ threshold concentration $\left(3 \mu \mathrm{g} \mathrm{L}^{-1}\right)$ proposed by Reynolds (1992, 1999) for identifying $\mathrm{P}$ as a limiting nutrient of the primary production. 


\subsection{Toxicity and uptake/depuration tests with Daphnia magna}

\subsubsection{Immobilization test by direct contact with adsorbents}

Figure 2 shows the concentration-response curves obtained in the immobilization tests with $D$. magna in direct contact with the four $\mathrm{P}$ adsorbents. As expected, all adsorbents caused an increased immobilization with increasing concentrations and contact time. In relation to the $\mathrm{EC}_{50}$, no statistically significant differences were found among the four studied adsorbents (Table 3 ).

To deliver data to be used in a preliminary ecological risk assessment of the four studied adsorbents Table 4 lists the PEC, PNEC and MAC-QS ${ }_{\mathrm{fw}}$, eco. The hypertrophic Honda lake (Almería, Spain) was chosen as a realistic case to illustrate the possible order of magnitude of environmental concentrations of the four $\mathrm{P}$ adsorbents. It should be noted that the PECs for all adsorbents were lower than $\mathrm{EC}_{50}$ for all adsorbents (Table 3 and Table 4). On the other hand the PECs for the Honda lake scenario exceeded the limit value for a short-term exposure $\left(\mathrm{MAC}-\mathrm{QS}_{\mathrm{fw}}\right.$, eco). This indicates some risk for aquatic organisms during the treatment of the lake which is to be expected due to the nature of the treatment. It should however be noted that lake restorations are undertaken in aquatic ecosystems that are in unbalance and since longer term effects of the adsorbents in the pelagic phase are not expected, this risk may on a case-to-case basis be acceptable.

The $\mathrm{EC}_{50}$ of HQ $\left(1.86 \mathrm{~g} \mathrm{~L}^{-1}\right)$ was higher, but not statistically significant, than that found in a similar experiment with D. magna (0.913 $\mathrm{g} \mathrm{L}^{-1}$; Álvarez-Manzaneda et al., 2017). The slight differences may be caused by the different media used in the two studies (M7 in the present study and distilled water in Álvarez-Manzaneda et al., 2017). In fact, and similarly to our results, several authors have noted a lower toxicity in experiments with daphnids in contact with M7 medium as a consequence of the underestimation of the toxicity of metal compounds since M7 has chelators added (Guilhermino et al., 1997; Loureiro et al., 2011). ForFe $\mathrm{O}_{4}$, and as expected, the $\mathrm{EC}_{50}\left(2.76 \mathrm{~g} \mathrm{~L}^{-1}\right)$ was much higher than $\mathrm{EC}_{50}$ and $\mathrm{LC}_{50}$ reported for much smaller $\mathrm{Fe}_{3} \mathrm{O}_{4}$ nanoparticles $(5-6 \mathrm{~nm}$; Baumann et al., 2014; García et al., 2011). This difference in toxicity may be related to particle sizes, but as pointed out by Hjorth et al. (2017) test technical issues like aggregation and sedimentation behavior in the different testing media makes it very challenging to obtain reliable and comparable results when testing Fe particles.

Lastly, it should be noted that the $\mathrm{EC}_{50}$ value for immobilization of $D$. magna when exposed to Phoslock ${ }^{\circledR}$ was 1.4-2.5 times higher than the $\mathrm{EC}_{50}$ values reported by Lürling and Tolman (2010) which were based on weight and length based growth rates of D. magna.

By visual inspection it was obvious that the particles might both have been ingested and been attached to the outer surfaces of the animals (Figure 3). As expected, daphnids present an empty gut and the carapace without any particle fixation in the control treatment (Figure 3a). However, when they are exposed to HQ they turned blackcolored (Figure 3b) reflecting both the ingestion and the attachment of these particles on their carapace. These results are in agreement with the concern of D. magna as a foodgeneralist organism with a mesh size in the filter appendices between 0.24 to $0.64 \mu \mathrm{m}$ (Geller and Müller, 1981) which is correlated with the range of particle size that $D$. magna can ingest. Although the mean particle size of HQ is $805 \pm 10 \mathrm{~nm}$ (Table 1) would indicate no ingestion of HQ according to the previous statement, however since the mean value does not account for the particle size distribution it is still possible that the smaller particles in the distribution could have been be ingested by daphnids. On the other hand, the smaller size of $\mathrm{Fe}_{3} \mathrm{O}_{4}(50-100 \mathrm{~nm}$; Table 1) could in theory have been too small for ingestion by daphnids however even smaller nanoparticles have been documented to be ingested by D. magna (e.g. Skjolding et al., 2014). Besides the possible ingestion of $\mathrm{Fe}_{3} \mathrm{O}_{4}$ visible body attachment was evident at the end of the testing 
period (Figure 3c). Although the size of $\mathrm{CFH}-12 \AA$ is too high to be ingested by daphnids, the colored gut present in Figure $3 \mathrm{~d}$ is likely to evidence both the filtration of a colored medium and the ingestion of the smaller particles by daphnids. Finally, the light color of Phoslock $®$ particles makes laborious to distinguish between ingestion and attachment on daphnids carapace (Figure 3d). However and considering the particle size of diluted Phoslock® (22 $\mu \mathrm{m}$, Haghseresht et al., 2009; Ross et al., 2008), it is likely that daphnids could ingest it.

\subsubsection{Immobilization test by indirect contact with adsorbents}

Apart from direct effect of MPs, it is essential to assess indirect effects on lake biota. These outcomes are especially relevant if we consider that in a practical application it is difficult to get $100 \%$ of MPs removal (Funes et al., 2017a) and accordingly, the remaining MPs are likely to interact for longer time and with complex mechanisms with lake biota.

Our results show much lower immobilization when D. magna was exposed in the indirect contact testing setup (Figure 4) than under direct contact (Figure 2). In fact, for all adsorbents less than $20 \%$ immobilization of the total number of animals was observed even at the highest concentration $\left(3.75 \mathrm{~g} \mathrm{~L}^{-1}\right.$; Figure 4$)$. These corresponding values were much higher in the direct contact testing setup $(60-100 \%)$ reflecting the prevalence of physical effects of $\mathrm{P}$ adsorbents rather than chemical induced toxicity. Similarly, previous studies with platinum nanoparticles $(1-10 \mathrm{~nm})$ and $D$. magna have found that these particles resulted in immobilization of the organisms due to a physical "fixation" rather than a toxic action (Sørensen et al., 2014).

As expected, daphnia body burdens of $\mathrm{Fe}$ and $\mathrm{La}$ increased with increasing adsorbent concentration (Figure 5). Although at higher adsorbent concentrations similar Fe contents were found, for low and mid adsorbent concentrations $\mathrm{Fe}$ content was higher for $\mathrm{CFH}-12 \circledR$ than for $\mathrm{HQ}$ and $\mathrm{Fe}_{3} \mathrm{O}_{4}$. Although there are no data about La content in $D$. magna in the literature making difficult the comparison of our results, Waajen et al. (2017) measured La content in different body part of different fish species after being in contact with Phoslock ${ }^{\circledR}$. These authors found the highest La concentration in the liver of eel while the lowest values were measured in the muscle of pike and perch.

\subsubsection{Uptake and depuration experiments}

The uptake kinetic was quite different among the studied adsorbents (Figure 6). After 1 $\mathrm{h}$ of contact time, the lowest $\mathrm{Fe}$ concentration was measured in tests with $\mathrm{Fe}_{3} \mathrm{O}_{4}(0.04$ $\mu \mathrm{g}$ daphnia $\left.^{-1}\right)$ while the highest was measured intests with HQ $\left(0.31 \mu \mathrm{g}\right.$ daphnia $\left.^{-1}\right)$. A clear increase in body burdens with time was found for tests with Phoslock®. This tendency was also observed for $\mathrm{HQ}$ and $\mathrm{Fe}_{3} \mathrm{O}_{4}$. In contrast, $\mathrm{Fe}$ uptake by daphnids in the presence of CFH-12® followed a steady pattern over time and in just $1 \mathrm{~h}$ of contact time the same amountas at the end of the uptake experiment $(24 \mathrm{~h})$ was found $(0.18 \mu \mathrm{g}$ daphnia $^{-1}$ ). In order to compare the uptake dynamic among all adsorbents, uptake rate constants $\left(\mathrm{K}_{\mathrm{u}}\right)$ were obtained (Table 5). From Table 5, it can be observed that although $\mathrm{K}_{\mathrm{u}}$ for HQ could not be determined, $\mathrm{K}_{\mathrm{u}}$ was highest for Phoslock $®\left(5.80 \mathrm{~h}^{-1}\right)$ and lowest for $\mathrm{CFH}-12 \AA\left(1.18 \mathrm{~h}^{-1}\right)$. Accordingly and in relation to $\mathrm{Fe}$ enriched adsorbents, it is important to remark that although $\mathrm{K}_{\mathrm{u}}$ was highest for $\mathrm{Fe}_{3} \mathrm{O}_{4}$, reflecting a fast uptake kinetic, at the end of the experiment the body burden was low due to a fast depuration. At this point, it is striking that higher Fe content in daphnids were found in contact with CFH-12® and HQ, which are specifically characterized by larger particle size (Table 1). Therefore, these results suggest that Fe uptake measured in this experiment is mostly due to Fe attachment on daphnids carapace rather than ingestion.

In the depuration test, when comparing the four $\mathrm{P}$ adsorbents, lowest depuration rate constant $\left(\mathrm{K}_{\mathrm{d}}\right)$ was found for $\mathrm{Fe}_{3} \mathrm{O}_{4}\left(2.04 \mathrm{~h}^{-1}\right)$ while highest corresponded to Phoslock $\circledR$ $\left(3.60 \mathrm{~h}^{-1}\right.$; Table 5). Similarly, elimination half-life time $\left(\mathrm{t}_{1 / 2}\right)$ was shortest for Phoslock ${ }^{\circledR}$ $(0.19 \mathrm{~h})$ and longest for $\mathrm{Fe}_{3} \mathrm{O}_{4}(0.34 \mathrm{~h})$. For the case of the residual body burden at the 
end of the depuration study, it was highest for HQ $\left(0.40 \mu \mathrm{g} \mathrm{Fe}\right.$ daphnia $^{-1}$; Figure 6) while very similar for $\mathrm{Fe}_{3} \mathrm{O}_{4}\left(0.03 \mu \mathrm{g}\right.$ Fe daphnia $\left.{ }^{-1}\right)$ and $\mathrm{CFH}-12 \circledR\left(0.06 \mu \mathrm{g}\right.$ Fe daphnia ${ }^{-}$ $\left.{ }^{1}\right)$. These concentrations were higher than the measured Fe-content of non-exposed animals $\left(0.003 \mu \mathrm{g}\right.$ Fe daphnia $\left.{ }^{-1}\right)$. For the case of Phoslock ${ }^{\circledR}$, residual body burden was similar to the background concentration $\left(3.5 \mathrm{ng} \mathrm{La}\right.$ daphnia $\left.{ }^{-1}\right)$. It is important to consider that the uptake-depuration experiment was carried out without feeding, and in similar experiments it has been observed that both the uptake was lower and the depuration faster in presence of food (Kennedy et al., 2008; Skjolding et al., 2014). All in all, taking this into account, and comparing the uptake and depuration rates, accumulation of adsorbents is not expected in daphnids in realistic exposure scenarios.

\section{Conclusions}

Results from algal growth rate inhibition tests have shown large differences among the four $\mathrm{P}$ adsorbents. In relation to the $\mathrm{EC}_{50}$ estimated in the immobilization test of $D$. magna by direct contact, no statistically significant differences were found among the four studied adsorbents.

For discriminating between physical effects and chemical induced toxicity, immobilization tests with $D$. magna by using a double-beaker were also carried out. Results clearly revealed much lower immobilization when D. magna was exposed through indirect contact with the adsorbents than under direct contact, which reflect the prevalence of a physical "fixation" of P adsorbents on daphnids carapace.

Finally, when comparing uptake and depuration rates among all studied adsorbents (except for HQ which was not possible not be fitted), our results evidenced a faster uptake and depuration for Phoslock®, which was precisely the adsorbent with the highest particle size. However, if we consider only Fe enriched adsorbents, there is no a clear tendency as the faster uptake rate was found for the adsorbent characterized by the smallest size $\left(\mathrm{Fe}_{3} \mathrm{O}_{4}\right)$ but it experienced the lowest depuration rates. Based on our findings, accumulation of adsorbents is not expected in daphnids in realistic exposure scenarios.

In a realistic worst-case scenario using data from Honda lake (Almería, Spain), some risk for aquatic organisms during the treatment of the lake was estimated, but most likely caused by physical effects of particles in the water phase. This risk may be on a case-to-case basis be acceptable, since lake restorations are undertaken in aquatic ecosystems that are in unbalance and neither accumulation nor longer term effects of the adsorbents in the pelagic phase are expected.

\section{Acknowledgments}

The authors thank Susanne Kruse for technical assistance in the laboratory. This work was supported by Junta de Andalucía project P10-RNM-6630 (Proyectos de Excelencia, Spain), MINECO CTM 2013-46951-R projects (Spain) and by the European Funding for the Regional Development (FondoEuropeo de Desarrollo Regional, FEDER).

\section{References}

Abot, A. R., Moscardi, F., Fuxa, J. R., Sosa-Gómez, D. R., Richter, A. R., 1995. Susceptibility of populations of Anticarsia gemmatalis (Lepidoptera: Noctuidae) from Brazil and the United States to a nuclear polyhedrosis virus. J. Entomol. Sci. 30, 62-69. http://dx.doi.org/10.18474/0749-8004-30.1.62

Álvarez-Manzaneda, I., Ramos-Rodríguez, E., López-Rodríguez, M.J., Parra, G., Funes, A., de Vicente, I., 2017. Acute and chronic effects of magnetic microparticles potentially used in lake restoration on Daphnia magna and Chironomus sp. J. Hazard. Mater. 322, 437-444. http://dx.doi.org/10.1016/j.jhazmat.2016.10.035 
Álvarez-Manzaneda, I., de Vicente, I., 2017. Assessment of toxic effects of magnetic particles used for lake restoration on Chlorella sp. and on Brachionus calyciflorus. Chemosphere 187, 347-356. http://dx.doi.org/10.1016/j.chemosphere.2017.08.129

Baumann, J., Köser, J., Arndt, D., Filser, J., 2014. The coating makes the difference: Acute effects of iron oxide nanoparticles on Daphnia magna. Sci. Total Environ. 484, 176-184. http://dx.doi.org/ 10.1016/j.scitotenv.2014.03.023

Chen, C.Y., Lin, K. C., 1997. Optimization and performance evaluation of the continuous algal toxicity test. Environ. Toxicol. Chem. 16, 1337-1344. http://dx.doi.org/10.1002/etc.5620160701

Christensen, E. R., Kusk, K. O., Nyholm, N., 2009. Dose-response regressions for algal growth and similar continuous endpoints: calculation of effective concentrations. Environ. Toxicol. Chem. 28 (4), 826-835. http://dx.doi.org/10.1897/08-068R.1

Cooke, D.G., Welch, E.B. Peterson S.A., Nicholas S.A., 2005. Restoration and Management of Lakes and Reservoirs, third ed. CRC Press, Boca Raton. pp. 3-8.

Cordell, D., Rosemarin, A., Schröder, J.J., Smit, A. L., 2011. Towards global phosphorus security: a systems framework for phosphorus recovery and reuse options. Chemosphere 84, 747-758. http://dx.doi.org/10.1016/j.chemosphere.2011.02.032.

de Jonge, V. N., Elliott, M., Orive, E., 2002. Causes, historical development, effects and future challenges of a common environmental problem: eutrophication. Hydrobiologia 475-476, 1-19. http://dx.doi.org/10.1023/A:1020366418295

de Vicente, I., Jensen, H.S., Andersen, F.Ø., 2008. Factors affecting phosphate adsorption to aluminum in lake water: Implications for lake restoration. Sci. Total Environ. 389, 29-36. http://dx.doi.org/10.1016/j.scitotenv.2007.08.040

de Vicente, I., Merino-Martos, A., Cruz-Pizarro, L., de Vicente, J., 2010. On the use of magnetic nano and microparticles for lake restoration. J. Hazard. Mater. 181, 375-381. http://dx.doi.org/10.1016/j.jhazmat.2010.05.020

de Vicente, I., Merino-Martos, A., Guerrero, F., Amores, V., de Vicente, J., 2011. Chemical interferences when using high gradient magnetic separation for phosphate removal: consequences for lake restoration. J. Hazard. Mater. 192, 995-1001. http://dx.doi.org/10.1016/j.jhazmat.2011.05.090.

Djomo, J. E., Garrigues, P., Narbonne, J. F., 1996. Uptake and depuration of polyclic aromatic hydrocarbons from sediment by the zebrafish (Bracydanio rerio). Environ. Toxicol. Chem.15 (7), 1177-1181. http://dx.doi.org/10.1002/etc.5620150724

Douglas, G.D., Adeney, J.A., Zappia, L.R., 2000. Sediment remediation project: laboratory trials 1998/9. Confidential report prepared for Water and Rivers Commission. CSIRO Land and Water Report no. 6/00. 92 pp.

Finsterle, K., 2014. Overview of Phoslock properties and its use in the aquatic environment. Phoslock Europe GmbH. pp. 33-34.

Fuchs, E., Funes, A., Saar, K., Reitzel, K., Jensen, H. S., 2018. Evaluation of dried amorphous ferric hydroxide $\mathrm{CFH}-12 \AA$ as agent for binding bioavailable phosphorus in lake sediments. Sci. Total Environ. 628-629, 990-996. http://dx.doi.org/10.1016/j.scitotenv.2018.02.059

Funes, A., de Vicente, J., Cruz-Pizarro, L., Álvarez-Manzaneda, I., de Vicente, I., 2016. Magnetic microparticles as a new tool for lake restoration: a microcosm experiment for evaluating the impact on phosphorus fluxes and sedimentary phosphorus pools. Water Res. 89, 366-374. http://dx.doi.org/10.1016/j.watres.2015.11.067.

Funes, A., Arco, A., Álvarez-Manzaneda, I., de Vicente, J., de Vicente, I., 2017a. A microcosm experiment to determine the consequences of magnetic microparticles 
application on water quality and sediment phosphorus pools. Sci. Total Environ. 579, 245-253. http://dx.doi.org/10.1016/j.scitotenv.2016.11.120

Funes, A., de Vicente, J., de Vicente, I., 2017b. Synthesis and characterization of magnetic chitosan microspheres as low-density and low-biotoxicity adsorbents for lake restoration. Chemosphere 171 ,

http://dx.doi.org/10.1016/j.chemosphere.2016.12.101

571-579.

Funes, A., Martínez, F. J., Álvarez-Manzaneda, I., Conde-Porcuna, J. M., de Vicente, J., Guerrero, F., de Vicente, I., 2018. Determining major factors controlling phosphorus removal by promising adsorbents used for lake restoration: A linear mixed model approach. Water Res. 141, 377-386. http://dx.doi.org/10.1016/j.watres.2018.05.029

García, A., Espinosa, R., Delgado, L., Casals, E., González, E., Puntes, V., Barata, C., et al., 2011. Acute toxicity of cerium oxide, titanium oxide and iron oxide nanoparticles using standardized tests. Desalination 269, 136-141. http://dx.doi.org/10.1016/j.desal.2010.10.052

Geller, W., Muller, H., 1981. The filtration apparatus of Cladocera: filter mesh-sizes and their implications on food selectivity. Oecologia 49 (3), 316-321. http://dx.doi.org/10.1007/BF00347591

Gilbert, N., 2009. Environment: The disappearing nutrient. Nature 461, 716-718. http://dx.doi.org/10.1038/461716a

Glibert, P. M., 2017. Eutrophication, harmful algae and biodiversity - Challenging paradigms in a world of complex nutrient changes. Mar. Pollut. Bull. 124, 591-606. http://dx.doi.org/10.1016/j.marpolbul.2017.04.027

Granados, Y. P., Ronco, A., Díaz-Báez, M. C., 2004. Ensayo de toxicidad crónica con el alga Selenastrum capricornutum (Pseudokirchneriella subcapitata)por el método de enumeracióncelular basado en el uso dehemocitómetro Neubauer in Castillo, G., (Ed.). Ensayos toxicológicos y métodos de evaluación de calidad de aguas. Estandarizacion, intercalibración, resultados y aplicaciones. IDRC, Ottawa. pp. 80-93.

Guilhermino, L., Diamantino, T. C., Ribeiro, R., Goncalves, F., Soares, A. M., 1997. Suitability of Test Media Containing EDTA for the Evaluation of Acute Metal Toxicity to Daphnia magna Straus. Ecotoxicol. Environ. Saf. 38(3), 292-295. http://dx.doi.org/10.1006/eesa.1997.1599

Haghseresht, F., Wang, S., Do, D. D., 2009. A novel lanthanum-modified bentonite, Phoslock, for phosphate removal from wastewaters. Appl. Clay Sci. 46, 369-375. http://dx.doi.org/10.1016/j.clay.2009.09.009

Hartmann, N. B., Engelbrekt, C., Zhang, J., Ulstrup, J., Kusk, K. O., Baun, A., 2013. The challenges of testing metal and metal oxide nanoparticles in algal bioassays: titanium dioxide and gold nanoparticles as case studies. Nanotoxicology 7, 1082-94. http://dx.doi.org/10.3109/17435390.2012.710657

Hjorth, R., Coutris, C., Nguyenc, N. H. A., Sevcuc, A., Gallego-Urrea, J. A., Baun, A. Joner, E. J., 2017. Ecotoxicity testing and environmental risk assessment of iron nanomaterials for sub-surface remediation - Recommendations from the FP7 project NanoRem. Chemosphere 182, 525-531. http://dx.doi.org/10.1016/j.chemosphere.2017.05.060

Hoffman, D. J., Rattner, B. A., Burton, Jr, G. A., Cairns, Jr, J., 2003. Handbook of Ecotoxicology, second ed. CRC Press, Boca Raton.

Hupfer, M., Hilt, S., 2008. Lake restoration, in: Jørgensen, S.E., Fath, B. (Eds.), Encyclopedia of Ecology. Elsevier, Oxford, pp. 2080-2093.

ISO, 2012. Water quality - Fresh water algal growth inhibition test with unicellular green algae. ISO, Geneva. 
Jeppesen, E., Søndergaard, M., Jensen, H. S., Ventäla, A. M., 2009. Lake and Reservoir Management, in: Likens, G. E. (Ed.), Encyclopedia of Inland Waters, 1. Elsevier, Oxford, pp. 295-309.

Jeske, D. R., Xu, H. K., Blessinger, T., Jensen, P., Trumble, J., 2009. Testing for the equality of $\mathrm{EC}_{50}$ values in the presence of unequal slopes with application to toxicity of selenium types. J. Agric. Biol. Environ. Stat. 14, 469-483. http://dx.doi.org/10.1198/jabes.2009.07088

Kennedy, R. H., Barko, J. W., James, W. F., Taylor, W. D., Godshalk, G. L., 1987. Aluminum sulfate treatment of a eutrophic reservoir: Rationale, application methods, and preliminary results. Lake Reserv. Manag. 3, 85-90. http://dx.doi.org/10.1080/07438148709354763

Kennedy, A. J., Hull, M. S., Steevens, J. A., Dontsova, K. M., Chappell, M. A., Gunter, J. C., Weiss, C. A., 2008. Factors influencing the partitioning and toxicity of nanotubes in the aquatic environment. Environ. Toxicol. Chem. 27, 1932-1941. http://dx.doi.org/10.1897/07-624.1

Khangarot, B. S., Ray, P. K., 1987. Correlation between heavy metal acute toxicity values in Daphnia magna and fish. Bull. Environ. Contam. Toxicol. 38, 722-726. http://dx.doi.org/10.1007/BF01608609

Landner, L., 1970. Lake restoration. Trials with direct precipitation of $\mathrm{P}$ in polluted lakes. Swedish Water Air Pollution Res Laboratory, Stockholm.

Lewis, M. A., 1995. Use of freshwater plants for phytotoxicity testing: A review. Environ. Pollut. 87, 319-336. http://dx.doi.org/10.1016/0269-7491(94)P4164-J

Lin, Q. W., He, F., Ma, J. M., Zhang, Y., Liu, B. Y., Min, F. L., Dai, Z. G., et al., 2017. Impacts of residual aluminum from aluminate flocculant on the morphological and physiological characteristics of Vallisneria natans and Hydrilla verticillata. Ecotoxicol. Environ. Saf. 145, 266-273. http://dx.doi.org/10.1016/j.ecoenv.2017.07.037

Liu, T. X., Hutchison, W. D., Chen, W., Burkness, E. C., 2003. Comparative Susceptibilities of Diamondback Moth (Lepidoptera: Plutellidae) and Cabbage Looper (Lepidoptera: Noctuidae) From Minnesota and South Texas $\lambda$-Cyhalothrin and Indoxacarb, J. Econ. Entomol. 94, 1230-1236. http://dx.doi.org/10.1603/0022-049396.4.1230

Loureiro, C., Castro, B. B., Pereira, J. L., Gonçalves, F., 2011. Performance of standard media in toxicological assessments with Daphnia magna: Chelators and ionic composition versus metal toxicity. Ecotoxicology 20, 139-148. http://dx.doi.org/10.1007/s10646-010-0565-1

Lürling, M., Tolman, Y., 2010. Effects of lanthanum and lanthanum-modified clay on growth, survival and reproduction of Daphnia magna. Water Res. 44, 309-319. http://dx.doi.org/10.1016/j.watres.2009.09.034

Lürling, M., Waajen, G., Van Oosterhout, F., 2014. Humic substances interfere with phosphate removal by lanthanum modified clay in controlling eutrophication. Water Res. 54, 78-88. http://dx.doi.org/10.1016/j.watres.2014.01.059

Lyngsie, G., Penn, C. J., Hansen, H. C. B., Borggaard, O. K., 2014. Phosphate sorption by three potential fi lter materials as assessed by isothermal titration calorimetry. J. Environ. Manage. 143, 26-33. http://dx.doi.org/10.1016/j.jenvman.2014.04.010

Mayer, P., Cuhel, R., Nyholm, N., 1997. A simple in vitro fluorescence method for biomass measurements in algal growth inhibition tests. Water. Res. 31 (10), 2525-2531. http://dx.doi.org/10.1016/S0043-1354(97)00084-5

Meis, S., Spears, B. M., Maberly, S. C., O’Malley, M. B., Perkins, R. G., 2012. Sediment amendment with Phoslock ${ }^{\circledR}$ in Clatto Reservoir (Dundee, UK): investigating 
changes in sediment elemental composition and phosphorus fractionation. J. Environ. Manage. 93(1), 185-193. http://dx.doi.org/10.1016/j.jenvman.2011.09.015

Menard, A., Drobne, D., Jemec, A., 2011. Ecotoxicity of nanosized $\mathrm{TiO}_{2}$. Review of in vivo data. Environ. Pollut. 159, 677-684. http://dx.doi.org/10.1016/ j.envpol.2010.11.027.

Merino-Martos, A., de Vicente, J., Cruz-Pizarro, L., de Vicente, I., 2011. Setting up high gradient magnetic separation for combating eutrophication of inland waters. J. Hazard. Mater. 186, 2068-2074. http://dx.doi.org/10.1016/j.jhazmat.2010.12.118.

Merino-Martos, A., De Vicente, J., Cruz-Pizarro, L., De Vicente, I., 2015. Single-ion interferences when using magnetic microparticles for phosphorus removal in aquatic ecosystems. Limnetica 34, 17-28.

Millington, L. A., Goulding, K. H., Adams, N., 1988. The influence of growth medium in composition on the toxicity of chemicals to algae. Water Res. 22 (12), 1593-1597. http://dx.doi.org/10.1016/0043-1354(88)90173-X

Morel, F. M. M., Price, N. M., 2003. The biogeochemical cycles of trace metals in the oceans. Science, 300(5621), 944-947. http://dx.doi.org/10.1126/science.1083545

Nogaro, G., Harris, A. M., Steinman, A. D., 2016. Alum application, invertebrate bioturbation, and sediment characteristics interact to affect phosphorus exchange in eutrophic ecosystems. Freshw. Sci. 35, 597-610. http://dx.doi.org/10.1086/685377

Núñez, M., Hurtado, J., 2005. Bioensayos de toxicidad aguda utilizando Daphnia magna Straus (Cladocera, Daphniidae) desarrollada en medio de cultivo modificado. Rev. Peru. Biol. 12, 165-170. http://dx.doi.org/10.15381/rpb.v12i1.2373

OECD, 1982. Eutrophisation des eaux. Méthodes de surveillanced'1evaluation et delutte. OECD, Paris.

OECD. 1984. Alga, Growth Inhibition Test. OECD, Paris.

OECD, 2004. Daphnia sp. Acute Immobilisation Test. OECD, Paris.

Pacioglu, O., Cornut, J., Gessner, M. O., Kasprzak, P., 2016. Prevalence of indirect toxicity effects of aluminium flakes on a shredder-fungal-leaf decomposition system. Freshw. Biol. 61, 2013-2025. http://dx.doi.org/10.1111/fwb.12529

Raven, J. A., Evans, M. C., Korb, R. E., 1999. The role of trace metals in photosynthetic electron transport in O2-evolving organisms. Photosyn. Res.60(2-3), 111-150. http://dx.doi.org/ 10.1023/A:1006282714942

Reitzel, K., Andersen, F. T., Egemose, S., Jensen, H. S., 2013. Phosphate adsorption by lanthanum modified bentonite clay in fresh and brackish water. Water Res. 47, 27872796. http://dx.doi.org/10.1016/j.watres.2013.02.051.

Reynolds, C. S., 1992. Eutrophication and the management of planktonic algae: what Vollenweider couldn't tell us, in: Sutclife, D. W., Jones, J. G. (Eds.), Eutrophication: Research and Application to Water Supply. Freshwater Biological Association, Ambleside (UK), pp. 4-29.

Reynolds, C. S., 1999. Metabolic sensitivities of lacustrine ecosystems to anthropogenic forcing. Aquat. Sci. 61, 183-205. http://dx.doi.org/10.1007/s000270050061

bb, M., Greenop, B., Goss, Z., Douglas, G., Adeney, J., 2003. Application of Phoslock TM, an innovative phosphorus binding clav, to two Western Australian waterways: preliminary findings. Hyrobiologia 237-243. http://dx.doi.org/10.1023/A:1025478618611

Ross, G., Haghseresht, F., Cloete, T. E., 2008. The effect of $\mathrm{pH}$ and anoxia on the performance of Phoslock ${ }^{\circledR}$, a phosphorus binding clay. Harmful Algae 7, 545-550. http://dx.doi.org/10.1016/j.hal.2007.12.007 
Sas, H., 1989. Lake restoration by reduction of nutrient loading: Expectations, experiences, extrapolations. Academia Verlag Richarz, St. Augustin.

Shcolnick, S., Keren, N., 2006. Metal homeostasis in cyanobacteria and chloroplasts. Balancing benefits and risks to the photosynthetic apparatus. Plant physiol.141(3), 805810. http://dx.doi.org/10.1104/pp.106.079251

Skjolding, L. M., Kern, K., Hjorth, R., Hartmann, N., Overgaard, S., Veinot, J. G. C., Baun, A., 2014. Uptake and depuration of gold nanoparticles in Daphnia magna. Ecotoxicology 23 (7), 1172-1183. http://dx.doi.org/10.1007/s10646-014-1259-x

Skjolding, L. M., Sorensen, S. N., Bloch, N., 2016. A Critical Review of Aquatic Ecotoxicity Testing of Nanoparticles. The Quest for Disclosing Nanoparticle Effects. Angew. Chem. Int. Ed. Engl. 55 (49), 15224-15239. http://dx.doi.org/10.1002/anie.201604964

Sørensen, S. N., Giron-Delgado, C., Engelbrekt, C., Baun, A., 2014. Platinum nanoparticle toxicity in freshwater algae and crustaceans: A physical or chemical effect? in Science Across Bridges, Borders and Boundaries: Programme Book Basel. SETACEurope, Switzerland.

Sørensen, S. N., Engelbrekt, C., Lützhøft, H. H., Jiménez-Lamana, J., Noori, J. S., Alatraktch, F. A., Delgado, et al., 2016. A multi-method approach for disclosing algal toxicity of platinum nanoparticles. Environ. Sci. Technol. 50 (19), 10635-10643. http://dx.doi.org/10.1021/acs.est.6b01072

Spears, B. M., Meis, S., Anderson, A., Kellou, M., 2013. Comparison of phosphorus (P) removal properties of materials proposed for the control of sediment $\mathrm{P}$ release in UK lakes. Sci. Total Environ. 442, 103-110. http://dx.doi.org/ 10.1016/j.scitotenv.2012.09.066

Spears, B. M., Mackay, E. B., Yasseri, S., Gunn, I. D. M., Waters, K. E., Andrews, C., Cole, S., et al., 2016. A meta-analysis of water quality and aquatic macrophyte responses in 18 lakes treated with lanthanum modified bentonite (Phoslock®). Water Res. 97, 111-121. http://dx.doi.org/10.1016/j.watres.2015.08.020

TGD-EQS, 2011. Technical Guidance for deriving Environmental quality standards, Guidance Document No. 27. Common Implementation Strategy for the Water Framework Directive (2000/60/EC). European Commission, Brussels.

van Oosterhout, F., Lürling, M., 2013. The effect of phosphorus binding clay (Phoslock®) in mitigating cyanobacterial nuisance: A laboratory study on the effects on water quality variables and plankton. Hydrobiologia 710, 265-277. http://dx.doi.org/10.1007/s10750-012-1206-X

Waajen, G., Pauwels, M., Lürling, M., 2017. Effects of combined flocculant Lanthanum modified bentonite treatment on aquatic macroinvertebrate fauna. Water Res. 122, 183-193. http://dx.doi.org/10.1016/j.watres.2017.05.075

Withers, P. J. A., Neal, C., Jarvie, H. P., Doody, D. G., 2014. Agriculture and eutrophication: Where do we go from here? Sustainability 6, 5853-5875. http://dx.doi.org/10.3390/su6095853

Yamada-Ferraz, T. M., Sueitt, A. P. E., Oliveira, A. F., Botta, C. M., Fadini, P. S., Nascimento, M. R., Mozeto, A. A., 2015. Assessment of Phoslock® application in a tropical eutrophic reservoir: an integrated evaluation from laboratory to field experiments. Environ. Technol. Innov. 4, 194-205.

http://dx.doi.org/10.1016/j.eti.2015.07.002 


\section{List of Tables}

Table 1. Main physic-chemical features of the $\mathrm{P}$ adsorbents used for this study. Concentrations (total and atomic surface) have been taken from Funes et al. (2018).

\begin{tabular}{|c|c|c|c|}
\hline Adsorbent & $\begin{array}{l}\text { Total }^{1} \text { and surface } \\
\text { concentration }(\%)\end{array}$ & Size & $\begin{array}{c}\text { Maximum P adsorption } \\
\text { capacity }\left(\mathrm{mg} \mathrm{g}^{-1}\right)\end{array}$ \\
\hline HQ & $\mathrm{Fe}(97.5) ; \mathrm{C}(0.9) ; \mathrm{O}(0.5) ; \mathrm{N}(0.9)^{1}$ & $\begin{array}{c}805 \pm 10 \mathrm{~nm} \\
\text { (de Vicente et al., 2010) }\end{array}$ & $\begin{array}{c}18.83 \\
\text { (de Vicente et al., 2010) }\end{array}$ \\
\hline $\mathrm{Fe}_{3} \mathrm{O}_{4}$ & $\mathrm{C}(59) ; \mathrm{Fe}(10) ; \mathrm{O}(31)^{2}$ & $\begin{array}{c}50-100 \mathrm{~nm} \\
\text { (manufacturer) }\end{array}$ & $\begin{array}{c}5.85 \\
\begin{array}{c}\text { (Funes et al., unpublished } \\
\text { results) }\end{array}\end{array}$ \\
\hline CFH-12® & $\begin{array}{c}\mathrm{O}(59) ; \mathrm{Fe}(28) ; \mathrm{C}(9) ; \mathrm{S}(2) ; \mathrm{Ca} \\
\text { and } \mathrm{Mg}(<1)^{2}\end{array}$ & $\begin{array}{c}0.85-2 \mathrm{~mm} \\
\text { (Fuchs et al., 2018) }\end{array}$ & $\begin{array}{c}15.1 \\
\text { (Funes et al., 2018) }\end{array}$ \\
\hline Phoslock® & $\begin{array}{l}\mathrm{O} \text { (66); } \mathrm{Si}(19) ; \mathrm{C}(6) ; \mathrm{Al}(6) ; \mathrm{Mg} \\
\mathrm{Na}, \mathrm{Ca}, \mathrm{Fe} \text { and } \mathrm{La}(<1)\end{array}$ & $\begin{array}{c}2-4 \times 1-3 \mathrm{~mm} \\
\text { (Haghsereht, 2006) }\end{array}$ & $\begin{array}{l}13.6 \\
\text { (Funes et al., 2018) }\end{array}$ \\
\hline
\end{tabular}

Table 2. Composition of the test solution used in the algal growth inhibition test (modified of ISO, 2012).

\begin{tabular}{ll}
\hline Major nutrients & mg L$^{-1}$ \\
\hline $\mathrm{NH}_{4} \mathrm{Cl}$ & 15 \\
$\mathrm{MgCl}_{2} \cdot 6 \mathrm{H}_{2} \mathrm{O}$ & 12 \\
$\mathrm{CaCl}_{2} \cdot 2 \mathrm{H}_{2} \mathrm{O}$ & 18 \\
$\mathrm{MgSO}_{4} \cdot 7 \mathrm{H}_{2} \mathrm{O}$ & 15 \\
$\mathrm{KH}_{2} \mathrm{PO}_{4}$ & 1.6 \\
$\mathrm{NaHCO}_{3}$ & 50 \\
\hline $\mathrm{Trace} \mathrm{elements}$ & $\boldsymbol{\mu g ~ \mathbf { L } ^ { - 1 }}$ \\
\hline $\mathrm{FeCl}_{3} \cdot 2 \mathrm{H}_{2} \mathrm{O}$ & 64 \\
$\mathrm{Na}_{2} \mathrm{EDTA}_{2} \cdot 2 \mathrm{H}{ }_{2} \mathrm{O}$ & 100 \\
$\mathrm{H}_{3} \mathrm{BO}_{3}$ & 185 \\
$\mathrm{MnCl}_{2} \cdot 4 \mathrm{H}_{2} \mathrm{O}$ & 415 \\
$\mathrm{ZnCl}_{2}$ & 3 \\
$\mathrm{CoCl}_{2} \cdot 6 \mathrm{H}_{2} \mathrm{O}$ & 1.5 \\
$\mathrm{CuCl}_{2} \cdot 2 \mathrm{H}_{2} \mathrm{O}$ & 0.01 \\
$\mathrm{Na}_{2} \mathrm{MoO}_{4} \cdot 2 \mathrm{H}{ }_{2} \mathrm{O}$ & 7 \\
\hline
\end{tabular}


Table 3. Results from 48 h $D$. magna immobilization test in direct contact with the studied adsorbents. Effect concentrations and corresponding $95 \%$ confidence intervals are all expressed in $\mathrm{g} \mathrm{L}^{-1}$.

\begin{tabular}{ccc}
\hline Adsorbent & EC50 (48 h) & EC10 (48 h) \\
\hline $\mathrm{HQ}$ & $1.86(0.61 ; 3.03)$ & $0.24(0 ; 0.68)$ \\
$\mathrm{Fe}_{3} \mathrm{O}_{4}$ & $2.76(1.45 ; 14.62)$ & $0.5(0 ; 1.11)$ \\
$\mathrm{CFH} 12 \AA$ & $2.26(1.67 ; 2.64)$ & $1.44(0.64 ; 1.86)$ \\
Phoslock ${ }^{\circledR}$ & $2.14(-;-)^{*}$ & $0.09(-;-)^{*}$ \\
\hline
\end{tabular}

Table 4. Comparison between predicted no-effect concentration (PNEC), predicted environmental concentration (PEC) and environmental quality standard of relevance (MAC-QSfw,eco), for R. subcapitata ${ }^{1}$ (algal growth inhibition test) and for D. magna ${ }^{2}$ (immobilization test with direct contact).

\begin{tabular}{cccc}
\hline Adsorbent & $\begin{array}{c}\text { PEC } \\
\left(\mathbf{m g ~ L}^{-1}\right)\end{array}$ & $\begin{array}{c}\text { PNEC } \\
\left(\mathbf{m g ~ L}^{-1}\right)\end{array}$ & $\begin{array}{c}\text { MAC-QS } \mathbf{f w} \\
\left(\mathbf{m g ~ L}^{-1}\right)\end{array}$ \\
\hline $\mathrm{HQ}^{1}$ & 350 & 1.50 & 15 \\
$\mathrm{Fe}_{3} \mathrm{O}_{4}{ }^{2}$ & 1120 & 2.76 & 27.6 \\
$\mathrm{CFH}^{1} 12{ }^{1}$ & 430 & 0.42 & 4.2 \\
Phoslock ${ }^{2}$ & 480 & 2.14 & 21.4 \\
\hline
\end{tabular}

Table 5. Uptake and depuration rate constants $\left(\mathrm{K}_{\mathrm{u}}\right.$ and $\mathrm{K}_{\mathrm{d}}$, respectively) and elimination half-life time $\left(\mathrm{t}_{1 / 2}\right)$ estimated in the uptake-depuration experiment with D. magna.

\begin{tabular}{cccc}
\hline Adsorbent & $\mathbf{K}_{\mathbf{u}}\left(\mathbf{h}^{-\mathbf{1}}\right)$ & $\mathbf{K}_{\mathbf{d}}\left(\mathbf{h}^{-\mathbf{1}}\right)$ & $\mathbf{t}_{\mathbf{1} / \mathbf{2}} \mathbf{( h )}$ \\
\hline $\mathrm{HQ}$ & - & - & - \\
$\mathrm{Fe}_{3} \mathrm{O}_{4}$ & 3.50 & 2.04 & 0.34 \\
$\mathrm{CFH}-12 \AA$ & 1.18 & 2.50 & 0.28 \\
Phoslock® & 5.80 & 3.60 & 0.19 \\
\hline
\end{tabular}




\section{List of Figures}

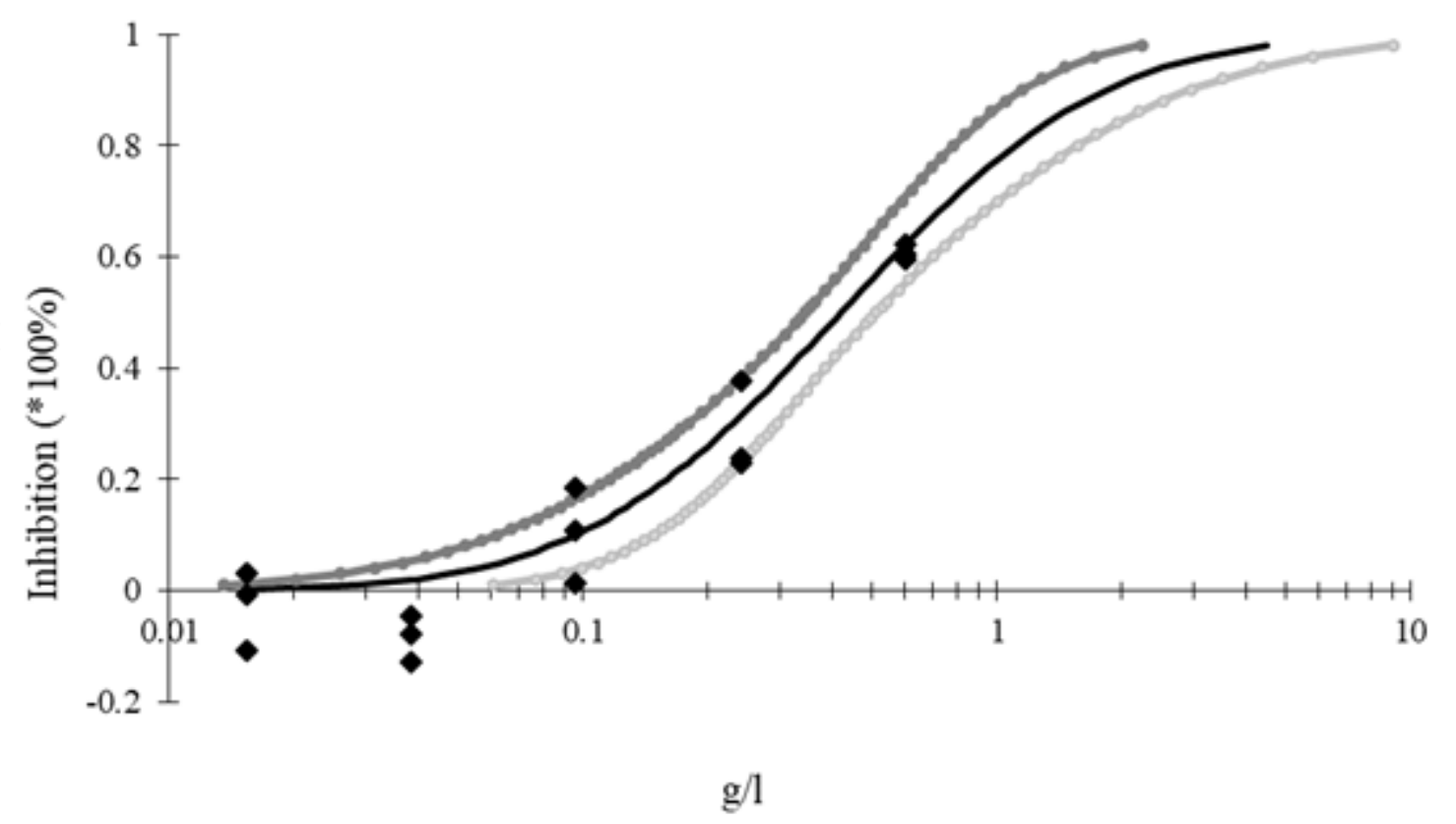

CFH-12® $\left(\mathrm{g} \mathrm{L}^{-1}\right)$

Figure 1. Concentration-response data and fitted curves from $72 \mathrm{~h}$ growth rate inhibition test with $R$. subcapitata and $\mathrm{CFH}-12 \AA$. Black diamonds represent observed values, black line shows the Log-normal distribution and light and dark grey lines represent the lower and upper $95 \%$ confidence interval at the concentration level, respectively. 

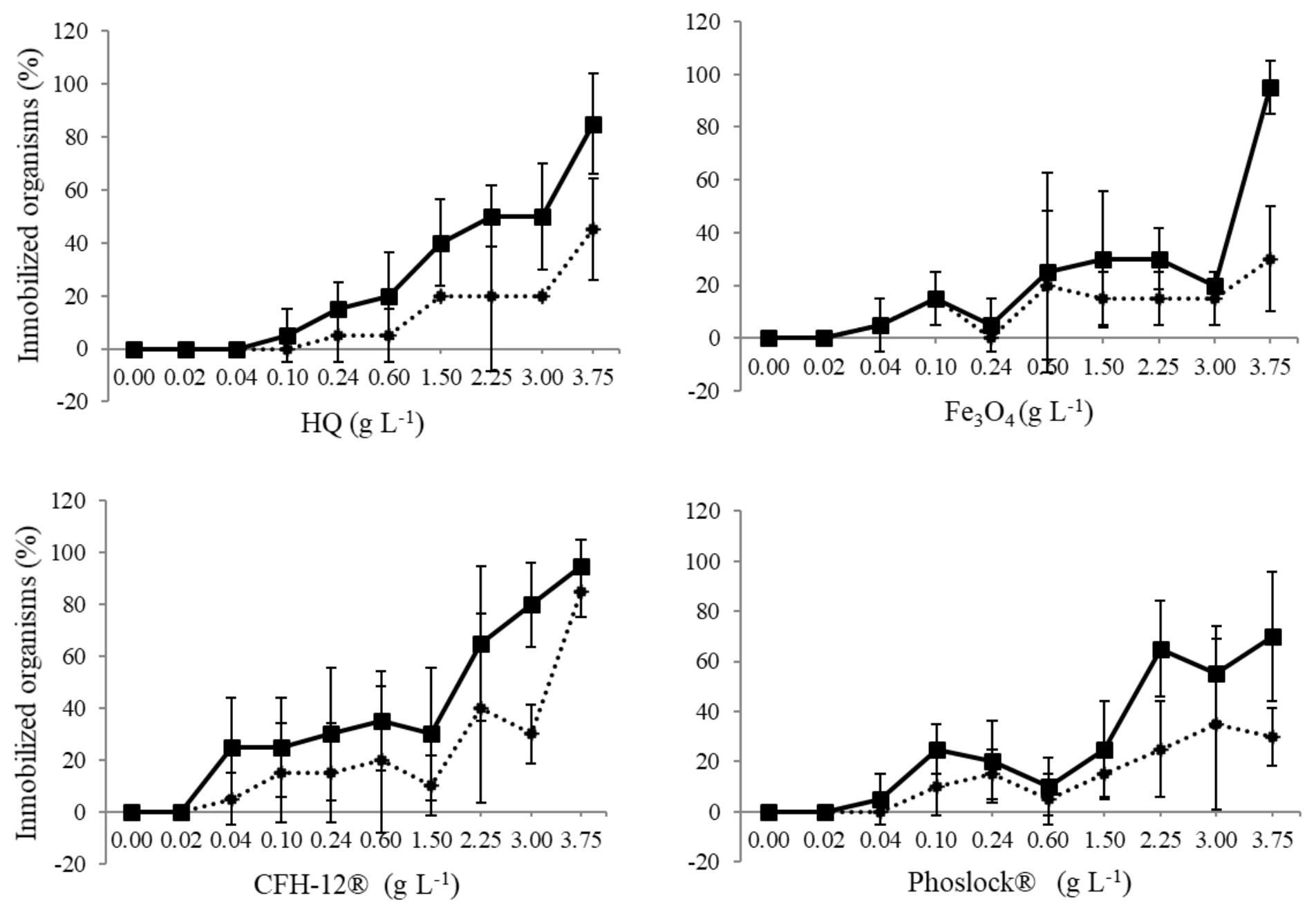

Figure 2. Individuals of D. magna immobilized (\%) after direct contact with the adsorbents for $24 \mathrm{~h}$ (dotted line) and $48 \mathrm{~h}$ (continuous line). Vertical error bars show standard deviation (SD). $\mathrm{n}=5$. 


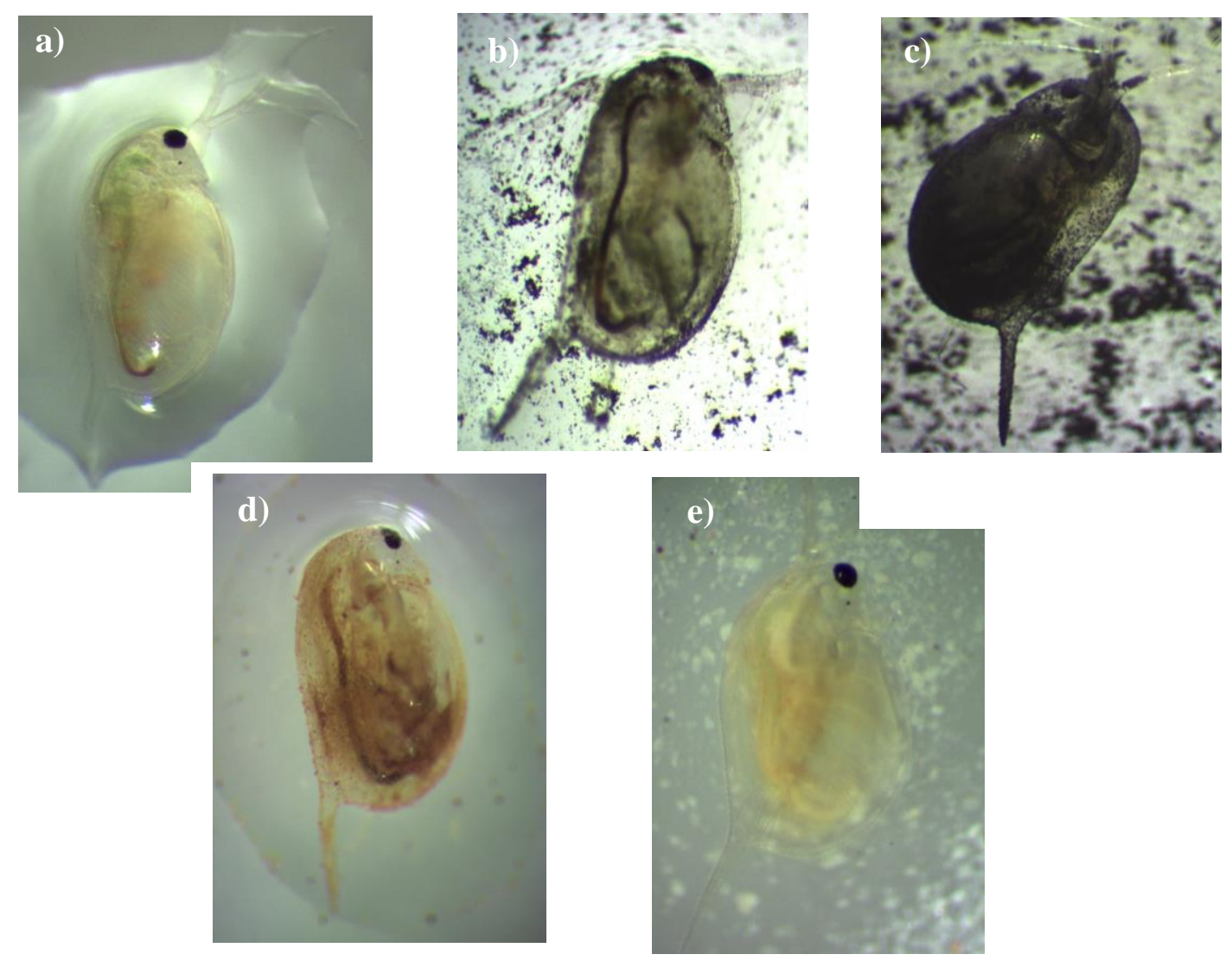

Figure 3. Photos of D.magna exposed, for $48 \mathrm{~h}$, in the immobilization test to direct contact with the adsorbents $\left(3.75 \mathrm{~g} \mathrm{~L}^{-1}\right.$ ). (a) Control; (b) $\mathrm{HQ}$; (c) $\mathrm{Fe}_{3} \mathrm{O}_{4}$; (d) $\mathrm{CFH}-12 ®$ and (e) Phoslock®. 

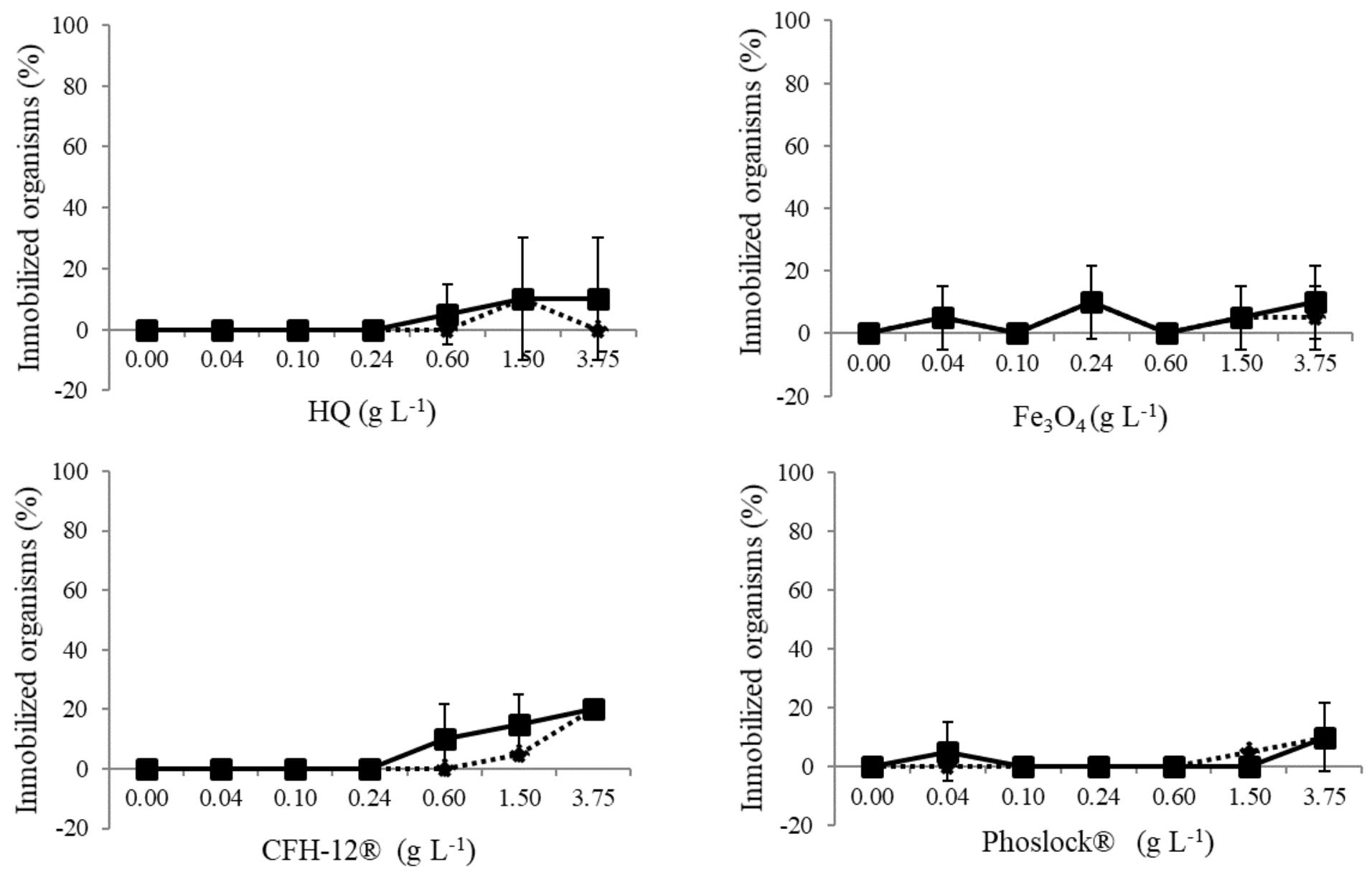

Figure 4. Individuals of D. magna immobilized (\%) after indirect contact with the adsorbents for $24 \mathrm{~h}$ (dotted line) and $48 \mathrm{~h}$ (continuous line). Vertical error bars show standard deviation $(\mathrm{SD}) . \mathrm{n}=5$. 

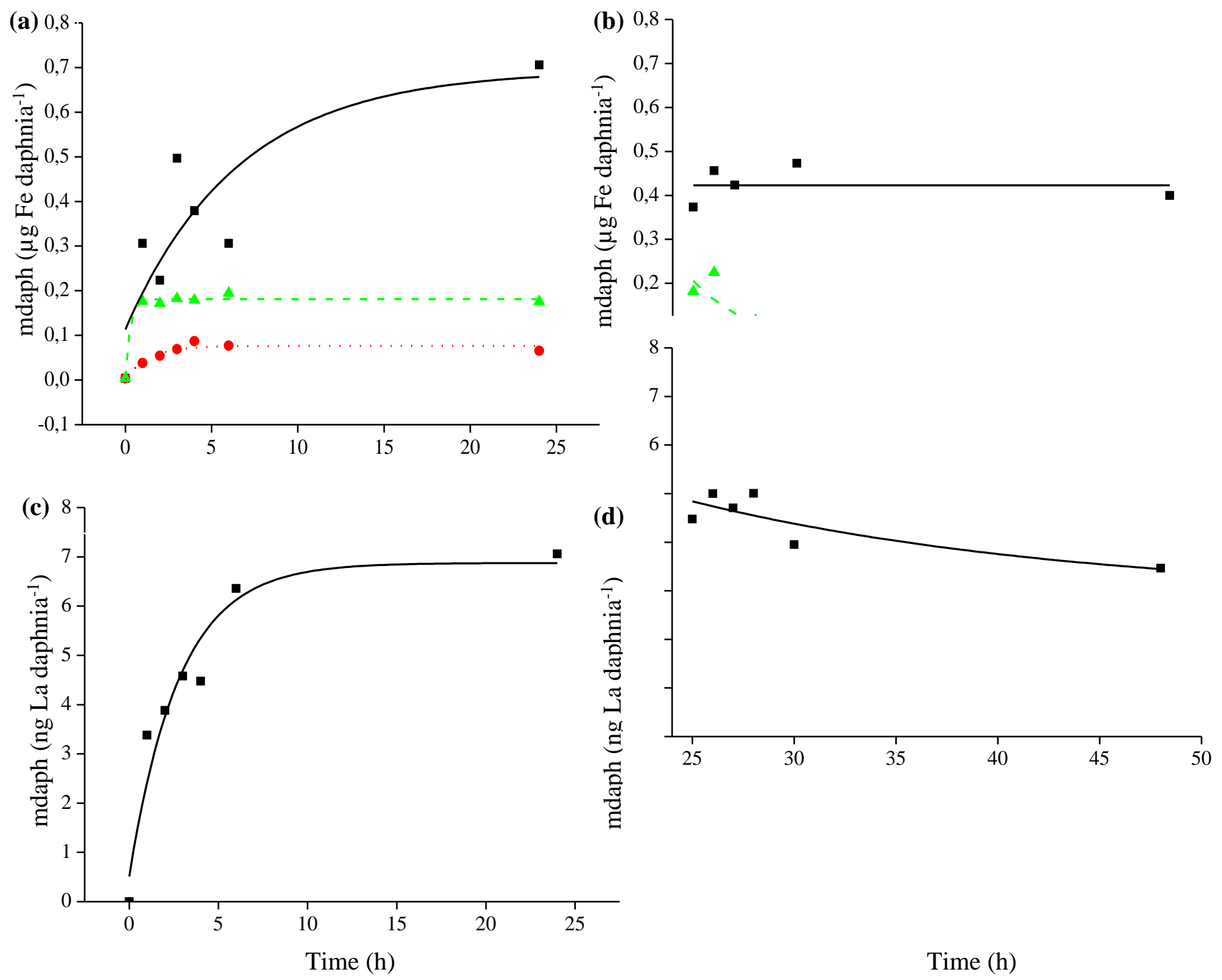

Figure 6. Temporal changes in the $(a ; c)$ uptake and $(b ; d)$ depuration tests in direct contact with the different $\mathrm{P}$ adsorbents. In Figures (a) and (b),squares, circles and triangles are refereed to $\mathrm{HQ}, \mathrm{Fe}_{3} \mathrm{O}_{4}$ and $\mathrm{CFH}-12 \AA$, respectively while in (c) and (d) Phoslock ${ }^{\circledR}$ results are shown. 